DOI: https://doi.org/10.31933/dijemss.v2i3 Received: $18^{\text {th }}$ January 2021, Revised: $15^{\text {th }}$ February 2021, Publish: $3^{\text {nd }}$ March 2021

\begin{tabular}{|c|c|c|}
\hline PUBAISHER & $\begin{array}{l}\text { DIJEMSS } \\
\text { DINASTI INTERNATIONAL JOURNAL } \\
\text { OF EDUCATION MANAGEMENT AND } \\
\text { SOCIAL SCIENCE }\end{array}$ & $\begin{array}{r}\text { https://dinastipub.org/DIJEMSS } \\
\text { editor@dinastipub.org } \\
08117401455\end{array}$ \\
\hline
\end{tabular}

\title{
THE AFFECT OF PERSONAL CHARACTERISTICS, MOTIVATION AND WORK DISCIPLINE AGAINST EMPLOYEE PERFORMANCE
}

\author{
Santi Maodia Fathonah ${ }^{1}$, Kasmir Kasmir ${ }^{2}$ \\ 1) Universitas Mercu Buana, Jakarta, Indonesia, santimaodiaf@gmail.com \\ ${ }^{2)}$ Universitas Mercu Buana, Jakarta, Indonesia, kasmir@mercubuana.ac.id
}

\section{Corresponding Author: Santi Maodia Fathonah}

Abstract: This research aims to investigate further regarding those influence which come from personal characteristics, motivation and work discipline towards employee performance at PT Hi-Lex Cirebon. The research population was employees from PT Hi-Lex Cirebon, with a total sample of 103 employees. The research method used a quantitative method. The data were processed through Structural Equation Model-Partial Least Square (SEM-PLS) analysis by SmartPLS 3.2.7 software. The results showed that the personal characteristics had a positive influence on employee performance, motivation had none relate to employee performance and work discipline had a positive influence on employee performance.

Keywords: Personal Characteristics, Motivation, Work Discipline, Employee Performance.

\section{INTRODUCTION}

Human resources is an crucial factor when running an organization because it does not directly affect the efficiency and effectiveness of the company. To build an excellent performance, PT.Hi-Lex Cirebon has made many improvements in the HR sector. Apart from that, PT. Hi-Lex Cirebon has acknowledge the value of technology in control cables, the company has endeavored to explore the potential of existing employees to involved in various research and development activities. However, based on the accurate data obtained, the quantity and quality of work which carried out during October 2019 to September 2020 did not reached the target yet, and even tended to decrease from the target set.

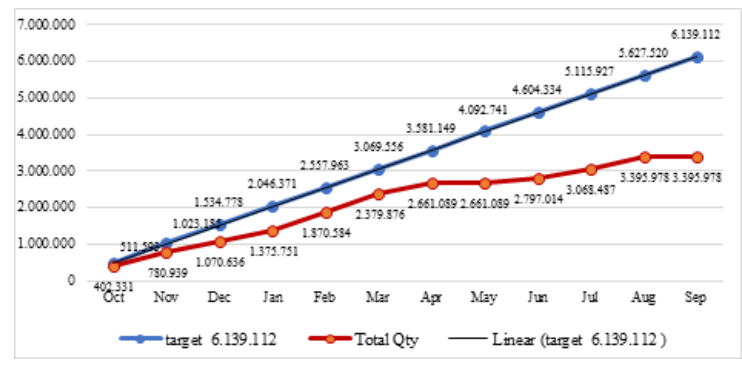


Figure 1. The Achievement from Assembly Section of PT Hi-Lex Cirebon in 2019-2020

Besides the employee performance that has not met the set standards, the phenomenon of indiscipline at PT Hi-Lex Cirebon has shown that the percentage of employee absenteeism during the last 10 months was still low (not reaching until 95\%) and below the set standard.

Then to reveal those factors which affect the employee performance at PT Hi-Lex Cirebon, the authors wereconducted a pre-survey to 20 respondents. According to these presurvey outcomes, it explains that the three variables which are thought having the most influence on employees performance of PT Hi-Lex Cirebon were motivation (60\%), work discipline $(70 \%)$ and personal characteristics $(75 \%)$.

Then according to these phenomena and pre-survey which has been carried out, the authors would like to further analysis with tittle of "The Affect of Personal Characteristics, Motivation and Work Discipline against Employee Performance." The aims of this research was to determine and analyze 1) the affect of personal characteristics on employee performance at PT Hi-Lex Cirebon, 2) the affect of motivation on employee performance at PT Hi-Lex Cirebon and 3) the affect of work discipline on employee performance at PT HiLex Cirebon.

\section{LITERATURE REVIEW Personal Characteristics}

Based on Hasibuan (2014) the personal characteristics is an individual traits which could be changed by environment or education.Meanwhile, based on Wibowo (2009), stated that personal characteristics are include motives, traits, and attitudes or it could be an easily observable characteristics such as skills and knowledge. Then According to Subekhi \& Jauhar (2013), Mostlythe dimensions of personal characteristics could be grouped into: biographical traits, personality, attitudes and abilities.

\section{Motivation}

Abraham Sperling in Mangkunegara (2013) argues that motivation could be defined as a tendency to do activities, starting from the drive in oneself (drive) and ending with self adjustment.Motivation is a positive urge for doing activity/work by a person for the sake of increasing a result of person's activities and aspirations. The theory of needs by Abraham Maslow (1970) in Edison et.al (2016) stated that motivation has 5 dimensions such as: physiological needs, safety needs, love and belonging needs, esteem needs, and selfactualization needs.

\section{Work Discipline}

Work discipline is an medium that exert by managers to interact with employees and make them transform their behavior in an effort to increase a person's awareness and enthusiasm to observe all company regulations and appliance social norms (Rivai, 2014). Meanwhile, according to Sinambela (2016) which explained that discipline is an obedience to the rules or orders that have been set by an organization or company. According to Hasibuan (2014), there are several factors which could impact the level of work discipline of employees on organization, such as: goals and abilities, role models, remuneration, justice, legal sanctions, assertiveness, and human connections. 


\section{Employee Performance}

Based on Mangkunegara (2013), the performance is an work outcome both in term of quality and quantity that reach by an employee in doing their respective job based on their liability. Meanwhile, according to Hasibuan (2014), performance is a work outcomes that reached by a person in accomplish the work that given to them according to their skills, practice, persistence and duration. Mathis \& Jakson in Sinambela (2016) argues that employee performance is influenced by quantity, quality, reliability, attendance, and teamwork ability.

\section{Previous Research}

According to the research outcomes from Nisakurohma \& Suharyono (2018) who reveal that personal characteristics had a significant impact on employee performance. Arisanti, et al. (2019), Nuraini \& Kasmir (2020) was found if there had a significant connection between work motivation on employee performance. Another factor which affects the employee performance besides personal characteristics is work discipline (Sinambela, 2016; Hasanah \& Lo, 2020). Dewi (2018) which found that personal characteristics, work discipline and motivation simultaneously affect the employee performance.Meanwhile, the research from Kalimeda (2018) which shows there is none impact from work discipline towards employee performance. Julianry, et al (2017) shows that motivation has a negative affect towards employee performance.

\section{Theoretical Framework}

Based on these phenomena, research object and those priors research whichhas been submitted, the theoretical framework that could be served as follows:

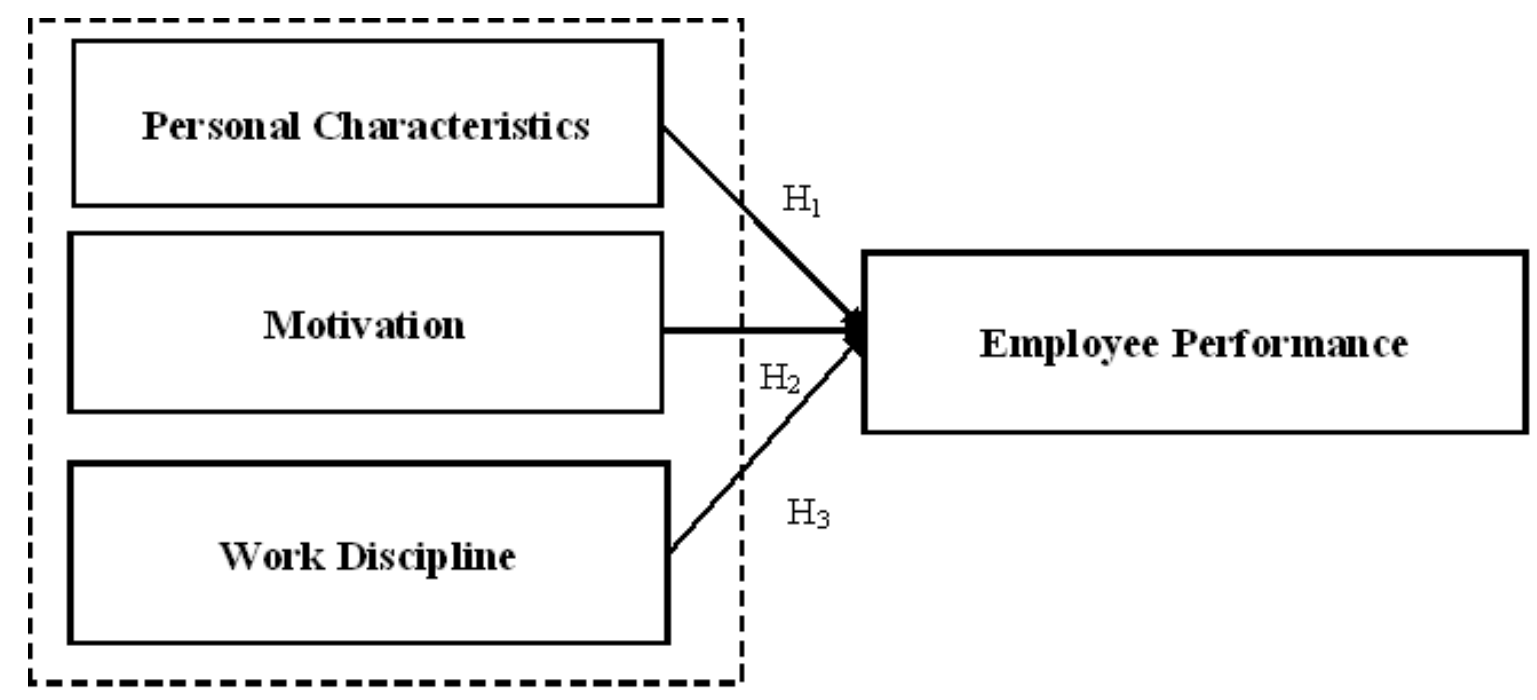

Figure 2. Theoretical Framework 


\section{Hypothesis}

According to the theoretical framework that has been described above, then the authors could formulate the hypothesis for this research which could be described as follows:

Hypothesis 1 (H1): Personal characteristics could affect employee performance.

Hypothesis 2 (H2): Motivation could affect employee performance.

Hypothesis 3 (H3): Work discipline affects employee performance.

\section{RESEARCH METHODS}

These analysis method was quantitative through causality approach. The exogenous variables in this research were personal characteristics, motivation and work discipline, while the endogenous variables was employee performance.The estimation scale in this research was a Likert scale.The research population were permanent employees of PT Hi-Lex Cirebon, with total of 140 employees, while the sample was 103 respondents (Slovin, 5\% error tolerance).The data analysis method used Structural Equation Modeling-Partial Least Square with the assist of the SmartPLS 3.0 program to examine the hypothesis.

\section{RESULT AND DISCUSSION Respondent Characteristics}

In accordance with the characteristics from these 105 respondents who are employees of PT Hi-Lex Cirebon, the majority of employees are female (52.4\%), 21-30 years old $(81.6 \%)$, high school education/equivalent $(90.3 \%)$ and have worked $>5$ years $(42.7 \%)$. This illustrates that the majority of employees of PT Hi-lex Cirebon are women of productive ages who have had worked at PT Hi-Lex Cirebon for a long time, so they already knew those work standards which expected by the company.

\section{Outer Model Measurement}

Based on the convergent validity test, it is known that whole indicators have a loading factor value $>0.5$, except for the KI12 indicator, so the indicator wasremoved from the model and second test was carried out.From these second test, all research indicators were declared valid.

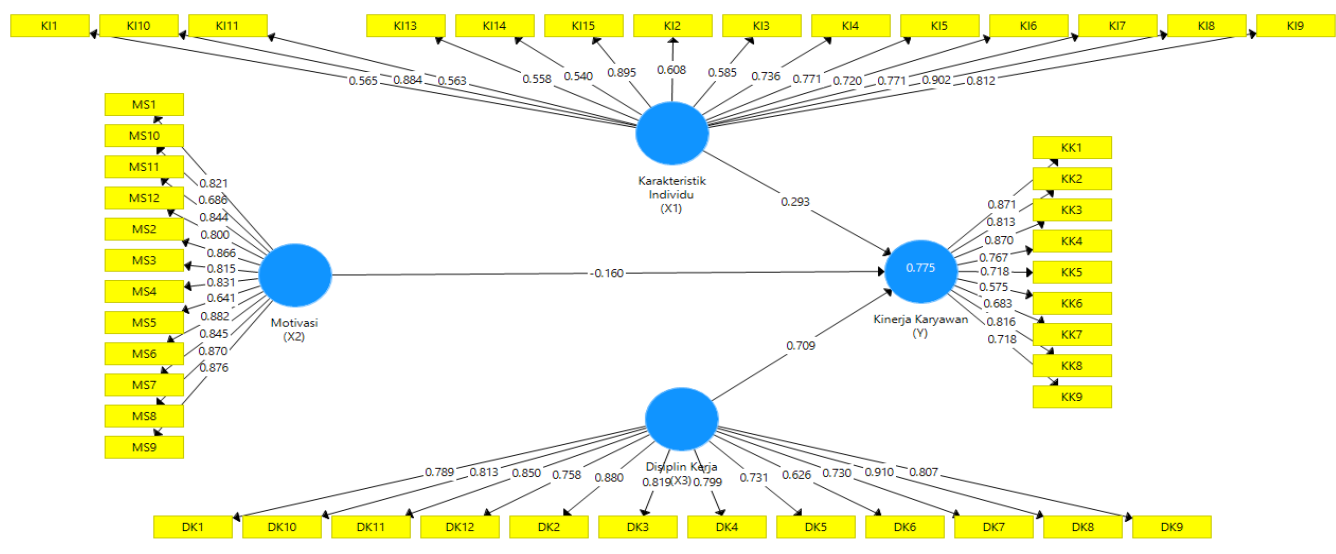

Figure 3.The PLS Algorithm (Modification) 
Based on the reliability test, it is known that all variables were stated reliable, because they had Cronbach's alpha value and composite reliability > 0.7 .

TablE 1. Reliability Test Result

\begin{tabular}{lccc}
\hline \multicolumn{1}{c}{ Variable } & Cronbach's Alpha & Composite Reliability & Information \\
\hline Motivation_(X2) & 0.954 & 0.960 & Reliable \\
Work Discipline_(X3) & 0.946 & 0.954 & Reliable \\
Employee Performance_(Y) & 0.909 & 0.926 & Reliable \\
Personal Characteristics_(X1) & 0.927 & 0.936 & Reliable \\
\hline
\end{tabular}

\section{$\mathbf{R}^{2}$ Test, Stone-Geisser $\left(Q^{2}\right)$, and GoF}

Based on the $\mathrm{R}^{2}$ test result, The personal characteristics, motivation and work discipline has a strong affect by $77.5 \%$ on employee performance.Then, according to the $\mathrm{Q}^{2}$ test it is known that the value of $\mathrm{Q}^{2}=0.429>0$, so this model has a good predictive relevance.Based on the GoF estimation results, then $\mathrm{GoF}=0.682>0.36$ results, so it could be interpreted that the mixed performance between measurement model (outer model) and structural model (inner model) was quite huge and good.

\section{Hypothesis Test}

The results from hypothesis test in this research which served like in these Table below.

Table 2. Hypothesis Test Results

\begin{tabular}{|c|c|c|c|c|c|}
\hline & $\begin{array}{l}\text { Original } \\
\text { Sample } \\
\text { (O) }\end{array}$ & $\begin{array}{l}\text { Standard } \\
\text { Deviation } \\
\text { (STDEV) }\end{array}$ & $\begin{array}{l}\text { T Statistics } \\
(\mid \mathrm{O} / \text { STDEV } \mid)\end{array}$ & $\begin{array}{c}\mathrm{P} \\
\text { Values }\end{array}$ & Information \\
\hline $\begin{array}{l}\text { Work Discipline (X3) } \\
>\text { Employee } \\
\text { Performance }(\mathrm{Y})\end{array}$ & 0.709 & 0.142 & 4.992 & 0.000 & $\begin{array}{l}\text { Positive- } \\
\text { Significant }\end{array}$ \\
\hline $\begin{array}{l}\text { Personal Characteristic } \\
\text { (X1) > Employee } \\
\text { Performance (Y) }\end{array}$ & 0.293 & 0.139 & 2.109 & 0.035 & $\begin{array}{l}\text { Positive- } \\
\text { Significant }\end{array}$ \\
\hline $\begin{array}{l}\text { Motivation (X2) > } \\
\text { Employee Performance } \\
\text { (Y) }\end{array}$ & -0.160 & 0.084 & 1.896 & 0.059 & $\begin{array}{c}\text { No Positive-No } \\
\text { Significant }\end{array}$ \\
\hline
\end{tabular}

According to these hypothesis test result which mentioned above, it written if the personal characteristics and work discipline had a positive and significant influence towards employee performance, while motivation has none.

\section{Discussion}

Based on hypothesis test in this research shows that personal characteristics have a positive and significant affect on employee performance. These outcomes were according to the Mangkunegara theory (2013), stated if the employee performance could affected by personal characteristics.Besides, these outcomes were strengthen the research from 
Nisakurohma \& Suharyono (2018) which stated that personal characteristics had a significant influence on employee performance. These results were in accordance with the conditions that occur in the company, where employees are still not good on understanding procedures at work, this could be seen from the production results which have not reached the target and the quality of production, as well as the attitudes and behavior of employees in carrying out work, they still need help or leads from superiors.so the employee performance still less good.

Based on hypothesis test in this research, it illustrate that motivation has none affect on employee performance. Besides, those results were confirmed the research from Julianry, et al (2017), and Changgriawan (2017) which found that motivation has no influence on employee performance. Meaning that work motivation at PT Hi-Lex Indonesia has been built, this could be seen from behave of the leadership at PT Hi-Lex Indonesia towards its employees, where the leadership always pays attention to the work done by employees, leveling the rights and obligations of each employee.Leaders always set an example in attitude, where the leaders will always implemented the $3 \mathrm{~S}$ attitudes (greetings, greetings and smiles). As well as an interview from one of the company leaders that the employee's rights have been fulfilled, such as providing incentives /salaries. So the factors that affect performance were outside the motivation variable.

Based on the hypothesis test in this research, it shows that work discipline has a positive and significant influence on employee performance. The results were in accordance with Sinambela's (2016) theory which stated that besides personal characteristics, another factor that affects employee performance is work discipline. In addition, these research outcomes were strengthen the research from Hasanah \& Lo (2020) that said if work discipline has a significant affect towards performance. Where when we viewed from these conditions in the company, the employees still have not been able to achieve the targets set by the company and they were still not fully able to complete production work according to the specified time. The quality of productions is still far from good, there are still products that are rejected/failed.

\section{CONCLUSION AND SUGGESTION Conclusion}

From these final outcomes and those discussion which carried out by the author, the conclusions that can be drawn based on proven of the hypothesis which built in this research, such as:

1) Personal characteristics have a positive and significant affect on employee performance at PT Hi-Lex Cirebon.

2) Motivation has none affect on employee performance at PT Hi-Lex Cirebon.

3) Work discipline has a positive and significant affect on employee performance at PT HiLex Cirebon.

\section{Suggestion}

After conduct the conclusions which resulting from data processed result, there are several suggestions that can be taken into consideration by PT Hi-Lex Indonesia or further researchers as follows: 
1) Companies need to be more intense to understand and realize the characteristics of each employee, one of way by carry out the sharing sessions.

2) Increase understanding aboutresponsibilities and procedures at work, in this case the company need to hold training regarding work procedures and socialization related to SOPs.

3) The company need to pay attention towards employee work discipline by conducting an evaluation of the achievement and compliance of employees in achieving the work standards which set by the company, so the employees would strive and capable to achieve the set work standards. Whereas if the employee success to reach the set work standards, then the employee deserves to received a reward.Meanwhile, employees who fail to achieve those standards would receive a warning.

4) Creating a conducive work environment, where a clean, comfortable and conducive work environment is an expected work environment by every employee. Through this conducive work environment, it will boost the employees to express themselves and provide new ideas, as well as increasing their motivation to become superior themselves.Companies could provide light sports facilities such as badminton or table tennis for employees which they can do during recess time so it will reduce the boredom at work.

5) It is advise for further research, which is the researchers could develop further by adding other variables, because employee performance could also be impacted by other variables. Just like pre-research which conducted by researchers predicted those factors are organizational culture, motivation, organizational commitment and leadership style. Perhaps it could be used as a reference for examining the variables which have not been described in this research.

\section{REFERENCES}

Arisanti, K.D., Santoso, A., \& Wahyuni, S. (2019). Pengaruh Motivasi Kerja Dan Disiplin Kerja Terhadap Kinerja Karyawan Pada PT Pegadaian (Persero) Cabang Nganjuk. Jurnal Ilmiah Mahasiswa EKonomi, 2(1), 101-118.

Changgriawan, G.S. (2017). Pengaruh Kepuasan Kerja dan Motivasi Kerja Terhadap Kinerja Karyawan di One Way Production. AGORA, 5(3).

Dewi, N.N. (2018). Pengaruh Karakteristik Individu, Disiplin Kerja, Dan Motivasi Terhadap Kinerja Pegawai. Media Mahardhika, 16(3), 403-413.

Edison, E., Yohny, A., \& Imas, K. (2016). Manajemen Sumber Daya Manusia. Bandung: Alfabeta.

Hasanah, F. \& Lo, S.J. (2020). The Mediating Role of Employee Satisfaction on The Influences of Employee Work Discipline, and Employee Motivation on Employee Performance at The Ministry of Transportation, The Republic of Indonesia, Research and Development Department. Dinasti International Journal of Management Science, 2(1), 1-11.

Hasibuan, S.P. (2014). Pengertian Manajemen Sumber Daya Manusia, Fungsi SDM, Pengawasan. Edisi Revisi. Jakarta: Bumi Aksara. 
Julianry, A., Syarief, R., \& Affandi, M.J. (2017). Pengaruh Pelatihan dan Motivasi Terhadap Kinerja Karyawan Serta Kinerja Organisasi Kementerian Komunikasi dan Informatika. Jurnal Aplikasi Bisnis dan Manajemen, 3(2), 236-245.

Kelimeda, K., Hairudinor, H., Ridwan, M.N.I, \& Dalle, J. (2018). The Effect of Motivation, Job Satisfaction and Job Discipline Toward Employee Performance of PT. Buma Perindahindo at Lng Tangguh Site, Teluk Bintuni Regency, West Papua, Indonesia. European Journal of Human Resource Management Studies, 2(1), 49-72.

Mangkunegara, A.A. (2013). Manajemen Sumber Daya Manusia Perusahaan. Bandung: PT Remaja Rosda Karya.

Nisakurohma, A.H., \& Suharyono, B.S. (2018). Pengaruh Karakteristik Individu Dan Lingkungan Kerja Terhadap Kinerja Karyawan (Studi Pada Karyawan PT Tigaraksa Satria Tbk Cabang Malang). Jurnal Administrasi Bisnis, 61(3), 109-115.

Nuraini, S., \& Kasmir, K. (2020). Company Strategy in Developing Human Resource Management and Work Motivation as an Effort to Improve an Employee Performance (Case Study of Training Management at PT. SMF, West Jakarta Branch)", Dinasti International Journal of Management Science, 2(1), 91-100.

Rivai, V. (2014). Manajemen Sumber Daya Manusia Untuk Perusahaan. Edisi 6. Depok: PT Raja Grafindo Persada.

Sinambela, L.P. (2016). Manajemen Sumber Daya Manusia: Membangun Tim Kerja Yang Solid Untuk Meningkatkan Kinerja. Jakarta: Bumi Aksara.

Subekhi, A \& Jauhar, M. (2013). Pengantar Teori Dan Perilaku Organisasi. Jakarta: Prestasi Pustaka.

Wibowo, F. (2009). Manajemen Kinerja. Jakarta: PT Raja Grafindo Persada. 